\title{
Applying Selected Quality Management Tools to Creation the Ecological Quality of Manufacturing Processes and Products
}

\author{
Stanisław Popek ${ }^{1,}$, Adam Popek $^{2}$ \\ ${ }^{1}$ Cracow University of Economics, Sienkiewicza St. 4, 30-033 Cracow, Poland \\ ${ }^{2}$ University of Physical Education in Cracow, Jana Pawła II 78, 31-571 Cracow, Poland
}

\begin{abstract}
The objective of this paper is to theoretically verify whether or not it is possible to apply some selected quality management tools to model the ecological quality of manufacturing processes and products in a company that is a plant manufacturing steel structures, traction towers, and lamp posts. Also, there are presented methods involving these selected quality management tools, and aiming at: solving problems occurring in this company, improving the quality of the company's products and services, and decreasing the production costs. With quality management tools applied to determining detrimental effects of manufacturing processes and products manufactured on the environment, it is possible to control them within the entire product's life cycle, as well to take effective corrective actions for the purpose of improving both the quality and the environment.
\end{abstract}

\section{Introduction}

A comprehensive study on product quality should refer, among other things, to human environment. Product quality is directly related to the customer's satisfaction and content, thus, it indirectly impacts all the environment components. A many domains encompassing definition of quality should contain ecological issues referring to both the products and manufacturing processes (including risk issues) [1,2].

This innovative approach to a problem of quality is identified and described as ecological quality. It can be portrayed as a dynamic system of quality-related profiles of products and manufacturing processes (production), where correlations among all those aspect are created, and ecological parameters and factors play a system-forming role [1-5].

With the predetermined ecological quality of products, it is also possible to evaluate the ecological compatibility during the entire life cycle of a product. In this way, strong and weak points of a product being manufactured can be identified and assessed. Furthermore, improvements can be made during individual phases of the product's life cycle, using, for example, appropriate quality tools. In addition, the following two requirements are deemed principles of ecological quality of products: a requirement to assure that unfavourable impacts on the environment are minimized, and a requirement limits of ecological

${ }^{1}$ Corresponding author: popeks@uek.krakow.pl 
acceptability are not exceeded during the phases of designing, manufacturing, utilizing, and disposing products. They apply both to the products and the methods \& processes of manufacturing and disposing them [1, 3, 6-10].

The objective of this paper is to theoretically verify whether or not it is possible to apply some selected quality management tools to model the ecological quality of manufacturing processes and products in a company that is a plant manufacturing steel structures, traction towers, and lamp posts. Also, there are presented methods involving these selected quality management tools, and aiming at: solving problems occurring in this company, improving the quality of the company's products and services, and decreasing the production costs.

\section{Applying some selected quality management tools to model ecological quality}

Quality management tools serve to collect and compile data connected with quality problems, they make it possible to control and influence designing, manufacturing, supervising, and assembling processes, as well as other procedures and actions during the entire product's life cycle. These tools can be applied individually or jointly for the purpose of picking out and analysing incompatibilities among the production processes and among the products; they also facilitate to study environmental impacts. Thanks to them, effective measures and actions can be taken to increase quality and to improve environmental protection [1- 8, 10, 17-19].

For the purpose of this paper, the tools as listed below are used; they serve as instruments to achieve the target assumed [11-16, 18]:

- Ishikawa diagram;

- Control charts:

- Pie charts;

- Pareto diagram (chart);

- Histogram

All these tools were employed in the company under consideration in order to assure high quality of manufactured products, and to reduce costs of manufacturing structures (both production and non-production costs). In the company, a special brainstorm action was organized, and specialists from different works departments participated in it. An Ishikawa diagram ensued from the brainstorm. With this diagram it was possible to identify reasons for failures and to depict interdependences among them. As next, this diagram was analysed, and the following actions were taken:

- In workstations additional lamps were installed;

- In spaces (rooms) with workstations, smoke (fumes) extractors were mounted;

- Curtains were hung near the gates and welding screens;

- Control charts were incorporated in the mass production;

- The first item of a fully tested and controlled novel product was accepted as a pattern and implemented in the production.

The Ishikawa diagram applied indicated that an incompatibility problem appeared in produced steel structures. Furthermore, it showed that this problem might generate increased outlays in manufacturing them, and, in consequence, the company could loose orders. And additional outlays led to higher pollution burdens of the environment, for example to increased gas and dust emission volumes.

In order to solve another problem: how to reduce production costs ensuing from gas emissions), a control chart was used presenting accidental deviations from the average level of emitted gas volumes. If an emitted gas quantity that exceeds admissible levels is early enough identified and determined, then, it is possible to correct a production process, and, therefore, to decrease manufacturing costs and pollution burdens of the environment. 


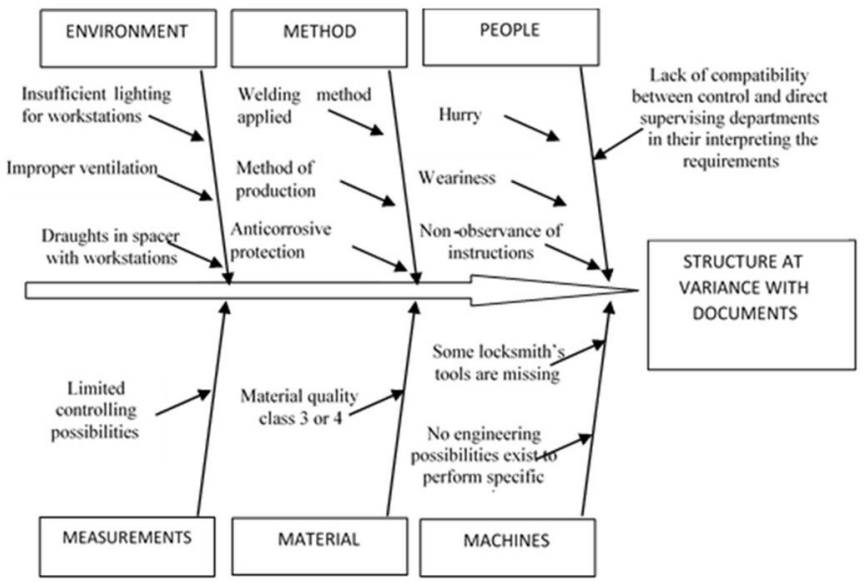

Fig. 1. Groups containing key factors of manufacturing processes (to manufacture steel structures) as shown in the cause-and-effect diagram.

Source: the author's own study on the basis of $[11,12,14,15,18]$

If any admissible limits are exceeded and this fact constitutes a risk to a manufacturing process, then, this failure must be corrected before control points exceed an allowable tolerance area.

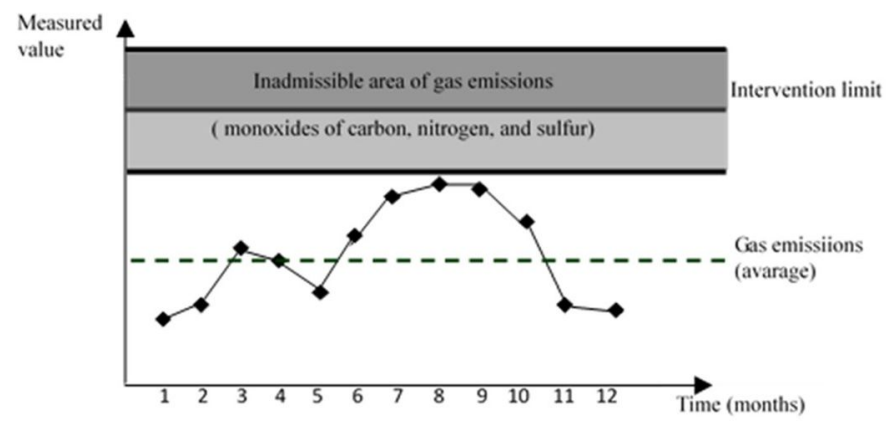

Fig. 2. Control Chart used to check quantities of gases produced and emitted during the production process of steel structures.

Source: the author's own study on the basis of $[5,6,9,12,14,16]$.

The pie charts as presented below refers to the impact of the manufacturing process of steel structures on the environment.

The pollution burdens of the environment are marked by lines; they are associated with relevant classes. On the basis of answers to questions contained in a special control list, occurrence frequency rates and magnitude levels of individual specific impact are determined.

Table 1. The pie charts.

\begin{tabular}{|r|l|l|l|}
\hline No. & Pollution Burden of the Environment & Number of processes - n & $\begin{array}{l}\mathrm{n} \\
{[\%]}\end{array}$ \\
\hline $\begin{array}{r}\text { 1. } \\
\text { Water (to straighten structures deformed } \\
\text { during welding), sanitary and domestic } \\
\text { wastewater) }\end{array}$ & HII II & 7 \\
\hline $2 . \begin{array}{l}\text { Air (gases emitted after welding, } \\
\text { cutting; radiation, noises) }\end{array}$ & $\begin{array}{l}\text { IIII IIII III IIII IIII } \\
\text { IIII IIII }\end{array}$ & 50 \\
\hline
\end{tabular}




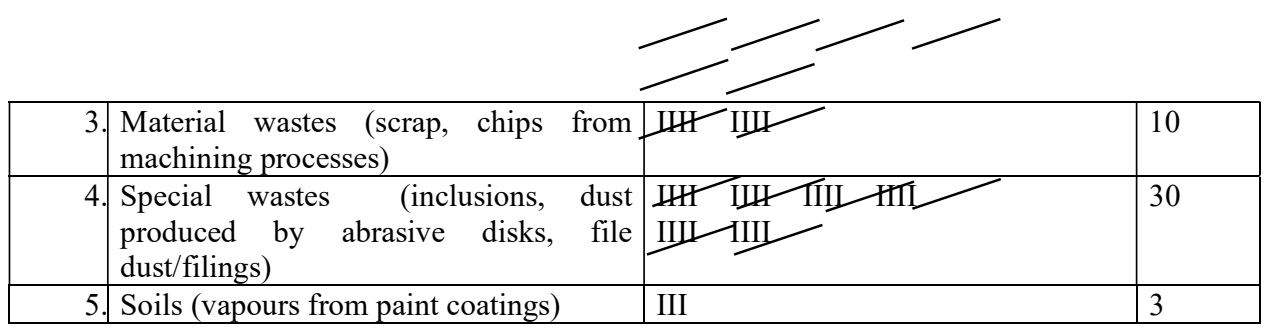

Source: the author's own study on the basis of $[4,7,13,14,16]$

The pie charts was used to determine wastes associated with the production profile, and the Pareto diagram - to show the evaluation of importance.

The analysis results of the pollution burdens of the environment (pie charts and Pareto diagram) can be utilized to reduce the environmental nuisance of those phenomena. In the company in question, modified holders in welding procedures replaced the old ones, and this manoeuvre resulted in an significantly lower gas consumption (up to $30 \%$ ). Moreover, mixes of gases were applied and, owing to this fact, the quality of fusion welds was improved, and the extent of a cleaning treatment needed to clean welded joints and to remove metal splatters and inclusions was reduced. The steps introduced and accomplished resulted in reduced volumes of emitted gas and dust (dust produced by abrasive disks).

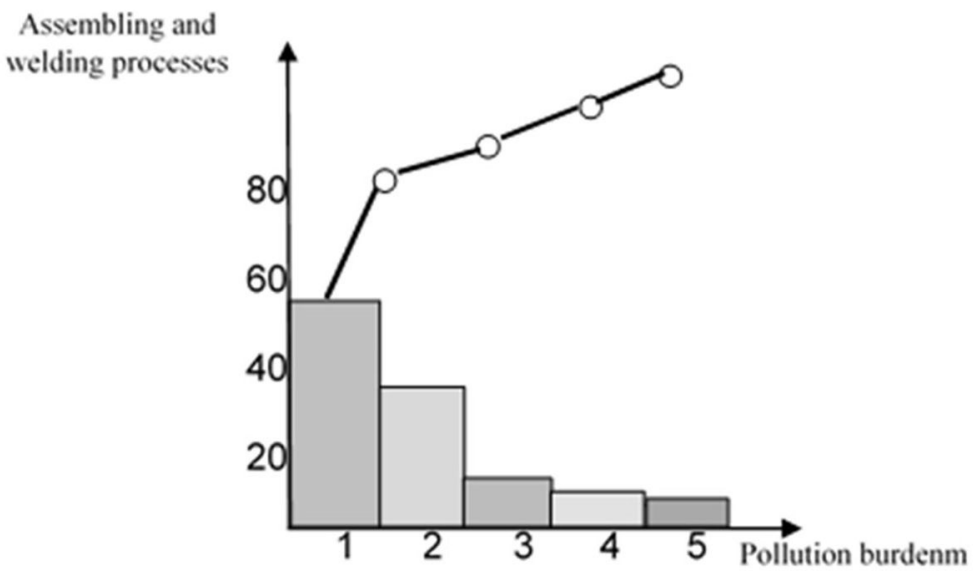

Fig. 3. Pareto Diagram referring to assembling and welding processes.

where:

1- Gases emitted during the welding processes, in the boiler house; noise and radiation;

2- Special wastes: inclusions from welds, dusts from abrasive disks, filings;

3- Material wastes - scrap produced during the mechanical or thermal cutting procedures, chips from machining processes;

4- Vapours produced while the structures were painted;

5- Sanitary and domestic wastewater and cooling water to cool welding holders; water necessary to straighten structures after the accomplished welding.

Source: the author's own study on the basis of $[5,6,8,14]$ 


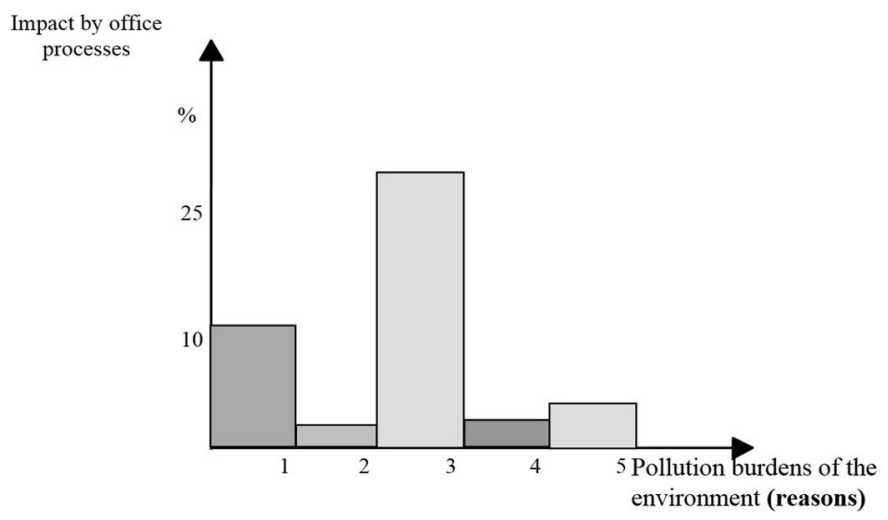

Fig. 4. Histogram of office processes.

where:

1- Paper wastes;

2- Water;

3- Land;

4- Special wastes;

5- Air.

Source: the author's own study on the basis of $[5,6,7,9,14]$

In order to find out whether or not the so called office expenses could be reduced, a histogram was made and analysed. While managing ecological quality, this tool enables to graphically display a variability distribution of quality trait or to show data on how technological processes proceed/behave. The above histogram displaying the impact of office processes on the environment was studied, and the analysis results served to correct negative effects depending on their extent. And, at the same time, it was possible to reduce non-production costs.

\section{Conclusions}

With quality management tools applied to determining detrimental effects of manufacturing processes and products manufactured on the environment, it is possible to control them within the entire product's life cycle, as well to take effective corrective actions for the purpose of improving both the quality and the environment [20-22].

The tools as described in this paper were applied in a plant manufacturing steel structures, traction towers and lamp posts. The main reason for their application was that customers complained about the defects in products they purchased, and therefore, problems appeared which needed to be remedied. These tools were used to find the best solutions for solving those problems, to analyze all the information collected from the customers, and to compare the plant's own production with the manufacturing processes running in the plants of competitors. The final result of the corrective actions taken was the reduction of manufacturing costs, the product quality improvement. The additional major effect of those actions was an enhanced company's image on the market (evidenced by the increasing number of letters of recommendation and a higher quantity of orders).

\section{References}

1. J. Janczak, E. Nowak, R. Pawłowski, K. Głowiński, Zeszyty Naukowe AON, 1, 180 (2014)

2. R. Pukala, Engineering Management in Production and Services, 8:3, 43 (2016) 
3. R. Pukala, E. Sira, R. Vavrek, Marketing and Management of Innovations, 3, 153 (2018)

4. B. Starzyńska, A. Hamrol, Z. Najlepszy, Zarządzanie przedsiębiorstwem, 2, 69, (2009)

5. T.P. Ryan, Statistical Methods for Quality Improvement. (Willey Series in Probability and Statistics, 3rd ed., Willey, New Jersey, 2011)

6. B. Starzyńska, Zeszyty Naukowe Politechniki Poznańskiej. Budowa Maszyn i Zarządzanie Produkcją, 13, 97 (2010)

7. K. Lisiecka, Systemy zarzadzania jakościa produktów. Metody, analizy $i$ oceny. (Wydawnictwo Akademii Ekonomicznej w Katowicach, Katowice, 2009)

8. A.P. Sage,W.B. Rouse, Handbook of Systems Engineering and Management, (Willey-Inter-science, New Jersey, 2009)

9. R. Wolniak, Parametryzacja kryteriów oceny poziomu dojrzałości systemu zarządzania jakościa, (Wydawnictwo Politechniki Śląskiej, Gliwice, 2011)

10. M. Petrova, Anale ATIC, Chisinau, Moldova, Evrica, 1:4, 63 (2004)

11. N.R. Tague, The quality toolbooks, (ASQ Quality Press, Milwaukee, Wisconsin, 2005)

12. D.C. Montgomery, Introduction to Statistical Quality Control, (John Wiley and Sons, New York, 2005)

13. M. Major, P. Stefanów, Zeszyty Naukowe 790, 104 (2008)

14. A. Hamrol, Zarządzanie jakościa z przyktadami (Wydawnictwo PWN, Warszawa, 2008)

15. B. Starzyńska, A. Hamrol, Total Quality Management \& Business Excellence, 24:5, $577(2013)$

16. D.C. Montgomery, Introduction to Statistical Quality Control, (John Willey and Sons, New York, 2005)

17. M. Petrova, M. Tepavicharova, L. Boykova, E3S Web of Conferences, 41, 04017, (2018)

18. M. Ćwiklicki, H. Obora, Wprowadzenie do metod TQM, (Wydawnictwo Uniwersytetu Ekonomicznego w Krakowie, Kraków, 2011)

19. Sv. Labunska, M. Petrova, O. Prokopishyna, Economic Annals - XXI. VOLUME 165:5-6, 13 (2017)

20. M. Petrova, N. Dekhtyar, O. Klok and O. Loseva, Problems and Perspectives in Management, 16:4, 259 (2018)

21. T. Odinokova, M. Bozhinova, M. Petrova, E3S Web Conferences, 41, 04015, (2018)

22. M. Petrova, SULSIT 14:1, 39 (2012) 